\title{
Hairy fleabane as a Source of Major Insect Pests of Soybean ${ }^{1}$
}

\author{
Buva como Fonte dos Principais Insetos-Praga da Soja
}

DALAZEN, G. ${ }^{2}$, CURIOLETTI, L.E. ${ }^{3}$, CAGLIARI, D. ${ }^{3}$, STACKE, R.F. ${ }^{3}$, and GUEDES, J.V.C. ${ }^{3}$

\begin{abstract}
Weeds compete with crops for essential inputs, but they are also important hosts for pests, both during the crop and between crops. Hairy fleabane (Conyza bonariensis) is an important weed growing in both summer and winter crops. The aim of this study was to evaluate the occurrence and population fluctuations of soybean pests using hairy fleabane as an alternative host. Samples of hairy fleabane plants were collected fortnightly over twelve months at two sites (Boa Vista do Incra and São Vicente do Sul) in Rio Grande do Sul state, Brazil. The results showed that hairy fleabane plants provided shelter to important soybean pests, including the pentatomid stink bugs Edessa meditabunda, Piezodorus guildinii, Dichelop sp. and Euschistus heros, especially after soybean maturation, and also served as an alternative food source. This weedy species was also an important alternative host for caterpillars such as Anticarsia gemmatalis, Chrysodeixis includens, Spodoptera spp. and Helicoverpa gelotopoeon.
\end{abstract}

Keywords: soybean pests, integrated pest management, weeds, Conyza bonariensis.

RESUMO - As plantas daninhas competem com as culturas por elementos essenciais, mas também são importantes hospedeiros para pragas, tanto durante quanto entre os cultivos. A buva (Conyza bonariensis) é uma importante planta daninha que cresce tanto em cultivos de verão quanto nos de inverno. O objetivo deste estudo foi avaliar a ocorrência e flutuação populacional de pragas da soja utilizando a buva como hospedeiro alternativo. Amostras de plantas de buva foram coletadas quinzenalmente durante 12 meses em duas localidades (Boa Vista do Incra e São Vicente do Sul), no Estado do Rio Grande do Sul, Brasil. Os resultados mostram que a buva fornece abrigo para pragas importantes da soja, incluindo os percevejos pentatomídeos Edessa meditabunda, Piezodorus guildinii, Dichelops sp. e Euschistus heros, especialmente após a maturação da soja, servindo também como fonte alternativa de alimento. Essa espécie de planta daninha também se mostra um importante hospedeiro alternativo para lagartas, como Anticarsia gemmatalis, Chrysodeixis includens, Spodoptera spp. e Helicoverpa gelotopoeon.

Palavras-chave: pragas da soja, manejo integrado de pragas, plantas daninhas, Conyza bonariensis.

\section{INTRODUCTION}

Weeds are considered the main limiting factor to agricultural production (Vila-Aiub et al., 2009), interfering with crops mainly by competing for essential inputs required for growth and development, such as water, light and nutrients (Dias et al., 2010). They may also act as hosts to pests and natural enemies, giving shelter or serving as a food source (Norris, 2005; Caballero-López et al., 2012; Foerster et al., 2015).
Although the presence of weeds in soybean fields (Glycine max) is undesirable, it is common due to deficiencies in control or the presence of herbicide-resistant weed species, such as Conyza bonariensis (Asteraceae), known as hairy fleabane. This weed species is very important, especially in the South of Brazil (Vargas et al., 2007). It is annual and has an enormous reproductive capacity and a potential to produce 200,000 seeds per plant, which are easily dispersed by the wind (Moreira et al., 2007). Its control has been

1 Recebido para publicação em 29.7.2015 e aprovado em 1.3.2016.

2 Universidade Federal do Rio Grande do Sul, Porto Alegre-RS, Brasil, < giliardidalazen@gmail.com>; ${ }^{3}$ Universidade Federal de Santa Maria, Santa Maria-RS, Brasil. 
difficult in recent years due to the selection of resistant populations to glyphosate (Vargas et al., 2007; Lamego and Vidal, 2008), a herbicide widely used to control weeds in soybeans, particularly for glyphosateresistant cultivars (GR) (Young et al., 2003; Christoffoleti et al., 2008).

The occurrence of hairy fleabane is common in some fields virtually during the whole year, where the control is inefficient during the summer crop, and when those areas used for pasture or left fallow, during the intercrop period, they do not receive any control measures. This situation has become worse with increased planting of glyphosatetolerant soybeans and reduction of populations of other weedy species in crops, thus making hairy fleabane one of the rare shelters and food sources for soybean pests when no crops are available.

Among the principal soybean pests is a complex of caterpillars, composed of species such as the velvetbean caterpillar (Anticarsia gemmatalis, 1818) and loopers (Chrysodeixis includens, 1857 and Rachiplusia nu, 1852), as well as the complex of pentatomid stink bugs, including the southern green stink bug (Nezara viridula, 1758), the neotropical brown stink bug (Euschistus heros, 1794), the redbanded stink bug (Piezodorus guildinii) and the species Dichelops furcatus, 177, D. melacanthus, 1851 and Edessa meditabunda, 1794 (Hoffmann-Campo et al., 2012). Other species of defoliating caterpillars from the genera Spodoptera and Helicoverpa also attack soybean pods.

Thus, based on the hypothesis that hairy fleabane act as a alternative host for soybean pests, the objectives of the present study were: (i) to evaluate the occurrence of soybean stink bugs and caterpillars on hairy fleabane plants and; (ii) to study the population fluctuations of these pest species on hairy fleabane plants over 12 months in two soybean producing regions of Rio Grande do Sul state (southern Brazil).

\section{METHODS}

This study was carried out in two soybeanproducing areas of Rio Grande do Sul state (southern Brazil): one in São Vicente do Sul (SVS) (2943’58" S; 5441'42" O), a county located in the Central Depression, and the one in Boa Vista do Incra (BVI) (28 56'06" S; $\left.53^{\circ} 26^{\prime} 08^{\prime \prime} \mathrm{O}\right)$, in the High Plains area. These areas are used as pastures to rear and fatten cattle during the autumn/winter period and for growing soybeans in the spring and summer.

Hairy fleabane plants were collected fortnightly for 12 months between sowing (November 2010), soybean development and harvesting, passing through the period of pasture (ryegrass + common oats) during the cold period, until the sowing of the following crop (November 2011). One hundred plants were collected randomly on each sampling date. Whole plants were bagged quickly (Byerly et al., 1978) to avoid insect escape and were removed by cutting close to the soil surface. Plants were then listed and stored in a refrigerator at $6{ }^{\circ} \mathrm{C}$ for at least 6 hours to reduce insect mobility, before separating, counting, labelling and mounting for later identification. When necessary for identification, larvae were reared to adults on an artificial diet (Greene et al., 1976) and also fed green leaves of hairy fleabane and soybeans in the rearing room of the Integrated Pest Management Laboratory (LabMIP), at the Federal University of Santa Maria (UFSM), with temperature of $25 \pm 1{ }^{\circ} \mathrm{C}$, relative humidity of $65 \pm 5 \%$ and a $14 \mathrm{H}$ photophase. Data were analyzed using the software program AnaFau (Moraes and Haddad, 2003) by calculating dominance, abundance, frequency and constancy.

\section{RESULTS AND DISCUSSION}

\section{Sucking bugs}

Five species of pentatomid (Hemiptera: Pentatomidae) stink bugs of the soybean stink bug complex (Table 1) were observed in Boa Vista do Incra (BVI): Edessa meditabunda, Dichelops spp., Piezodorus guildinii, Nezara viridula and Euschistus heros. E. meditabunda was the predominant species, dominant (D), very abundant (va), very frequent (vf) and constant (W), with 76 individuals collected during the sampling period. Besides, the most 
Table 1 - Faunistic analysis of soybean Hemiptera (Pentatomidae) stink bugs found on hairy fleabane plants (Conyza bonariensis) in Boa Vista do Incra and São Vicente do Sul

\begin{tabular}{|c|c|c|c|c|c|}
\hline Taxa & Total & Domin. ${ }^{\prime}$ & Abund. ${ }^{\prime}$ & Freq..$^{3 /}$ & Const. ${ }^{4 /}$ \\
\hline Hemiptera (Pentatomidae) & \multicolumn{5}{|c|}{ Boa Vista do Incra } \\
\hline Edessa meditabunda* & 76 & $\mathrm{D}$ & va & vf & W \\
\hline Euschistus heros & 12 & $\mathrm{D}$ & va & $\mathrm{f}$ & $\mathrm{Z}$ \\
\hline Dichelops spp. & 4 & ND & va & $\mathrm{f}$ & $\mathrm{Z}$ \\
\hline Piezodorus guildinii & 4 & ND & va & $\mathrm{f}$ & Z \\
\hline \multirow[t]{2}{*}{ Nezara viridula } & 1 & ND & va & $\mathrm{f}$ & Z \\
\hline & \multicolumn{5}{|c|}{ São Vicente do Sul } \\
\hline Edessa meditabunda & 1 & ND & va & $\mathrm{f}$ & $\mathrm{Z}$ \\
\hline Piezodorus guildinii & 5 & $\mathrm{D}$ & va & $\mathrm{f}$ & $\mathrm{Z}$ \\
\hline
\end{tabular}

* Predominant specie; 1/Dominance: ND (non-dominant); D (dominant); SD (super dominant); ํ'Abundance: $\mathrm{r}$ (rare); d (dispersed); c (common); a (abundant); va (very abundant); sa (super abundant); ${ }^{3}$ Frequency: If (little frequent); $\mathrm{f}$ (frequent); vf (very frequent); sf (super frequent); ${ }^{4 /}$ Constancy: Z (accidental); Y (acessory); W (constant).

common species were E. heros, with 12 individuals, Dichelops spp. and P. guildinii, with four individuals each and $N$. viridula, with one individual.

Although E. meditabunda is considered a secondary pest in soybeans, it can occasionally cause considerable damage in Rio Grande do Sul and the Midwest region of Brazil (CorrêaFerreira and Panizzi, 1999). These authors rate this species as having a low damage potential as it does not feed exclusively on grains, in contrast to other soybean stink bug species. E. meditabunda also feeds on soybean stems (Corrêa-Ferreira and Panizzi, 1999), and this may be a reason for the high numbers of this species found on hairy fleabane since it has been observed while feeding on the stems of this weed. The occurrence of pentatomid stink bugs in São Vicente do Sul (SVS) (Table 1) was lower than in BVI, with only two species observed: P. guildinii, with five individuals and E. meditabunda, with only one individual. This may have been due to the fact that soybean areas at SVS in the Central Depression are non-continuous compared to the continuous crop areas in the High Plains, where BVI is located.

The population fluctuations of pentatomid stink bugs in BVI and SVS are shown in Figures 1 and 2, respectively. Stink bugs were observed on hairy fleabane in BVI from the very first evaluations in November (Figure 1), extending until the end of the vegetative stage in soybeans. However, as the soybean plants initiated their reproductive phase, which is the preferred one by stink bugs, the number of pentatomid stink bugs on hairy fleabane plants decreased to zero between January and March. This mobility between hairy fleabane and soybean plants in the reproductive stage illustrates that $C$. bonariensis may act as an alternative host for stink bugs, mainly before the reproductive soybean stage. Normally, the colonization of the soybean crop by stink bugs begins at the end of the soybean vegetative stage or soon after flowering (Panizzi and Vivan, 1997). At this time, stink bugs emerge from diapause or migrate from alternative host

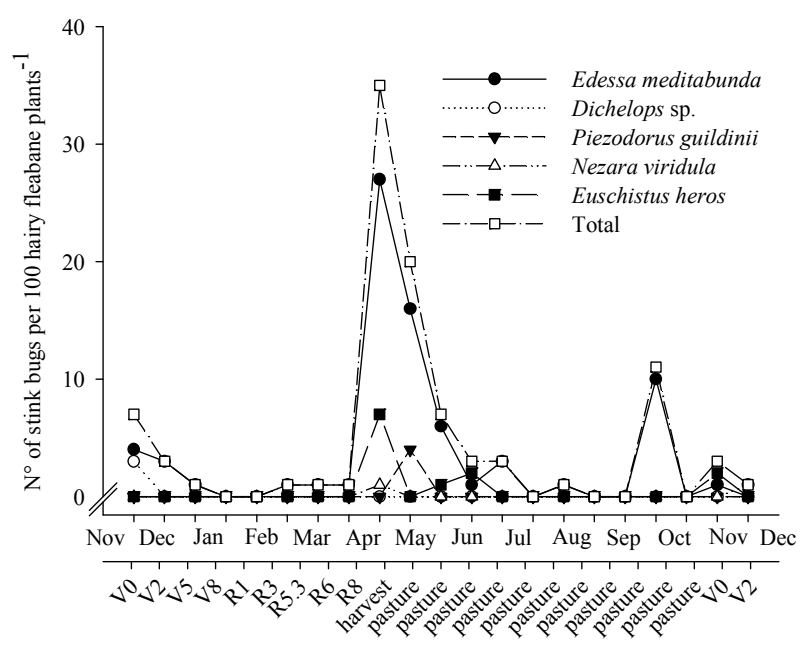

Figure 1 - Population fluctuations of Hemiptera (Pentatomidae) stink bugs associated with hairy fleabane plants (Conyza bonariensis) in Boa Vista do Incra, RS. 
plants to soybeans (Corrêa-Ferreira and Panizzi, 1999). The low numbers of stink bugs on hairy fleabane plants were maintained until mid-March.

The development of soybean pods and grains makes the crop nutritionally more suitable for stink bug development and, consequently, increase in their populations. After this period, a peak in the numbers of pentatomid stink bugs was observed on hairy fleabane plants, mainly of the species E. meditabunda, E. heros and $P$. guildinii, which may be attributed to soybean maturation. Thus, the insects migrate from the maturing plants (stages R7 and R8), which are inappropriate for their feeding due to the hardness of the integument and thickness of the pods (Panizzi, 1991), to hairy fleabane plants, which are the only green species present at this time. After grain filling in the soybeans, the stink bug population tends to decrease and, at harvest, the remaining stink bugs move to alternative hosts, such as hairy fleabane and other weed species (Corrêa-Ferreira and Panizzi, 1999; Corrêa-Ferreira and Peres, 2003). Thus, stink bugs may complete a life cycle before entering diapauses, as nymphs were also found on hairy fleabane plants.

During August and September, there were practically no stink bugs present. At this time, food is scarce and the photoperiod is significantly reduced. When there are no soybeans or other food sources, and the temperature and photoperiod decrease, adult $E$. heros enter diapause and stay on leaves in the soil, without feeding or reproducing (Panizzi and Niva, 1994). Similarly, in $N$. viridula, diapause is regulated by a shortening of the photoperiod (MUSOLIN, 2012). Stink bugs are observed on hairy fleabane plants from the beginning of October due to the increase in temperature and photoperiod, and the adults emerge from diapause and feed and reproduce on the crop or alternative hosts.

Although the numbers of soybean pentatomid stink bugs on hairy fleabane plants in SVS were small (Figure 2), population fluctuations were similar to those observed in BVI, with two periods of occurrence. The first was at the beginning of soybean cultivation,

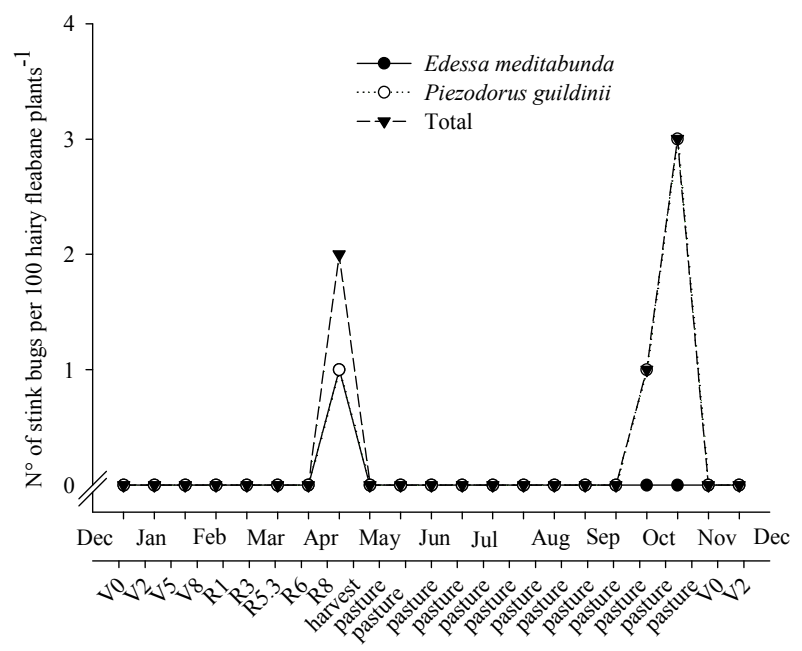

Figure 2 - Population fluctuations of Hemiptera (Pentatomidae) stink bugs associated with hairy fleabane plants (Conyza bonariensis) in São Vicente do Sul, RS.

during the sowing and emergence periods, and the second period was at soybean maturation, when the stink bugs migrate from the soybean to hairy fleabane plants, which are a food source for completing the stink bug generation. Thus, it is clear that hairy fleabane is an important host for soybean stink bugs, especially during these two periods. Firstly, in the spring, at the beginning of soybean plant growth, and later when the crop is maturing (stages R7 and R8), when it becomes unsuitable for pest consumption. The emergence of hairy fleabane seedlings in two periods during the year - one in autumn and the other in spring, when temperatures reach $20{ }^{\circ} \mathrm{C}$ - is ideal for germination (Lazaroto et al., 2008). Therefore, control of hairy fleabane plants from both periods of germination in southern Brazil is fundamental. The presence of hairy fleabane plants acts as a green bridge during the intercrop period, favoring the occurrence of the first generations of stink bugs and also the finalization of other generations at the end of the crop.

\section{Defoliating caterpillars}

The occurrence of lepidoptera larvae (Lepidoptera: Noctuidae) (Table 2) was higher in BVI, as was also observed for stink bugs. Six species of lepidoptera larvae were found in BVI and five in SVS. In both places, A. gemmatalis, Spodoptera frugiperda and 
Table 2 - Faunistic analysis of soybean caterpillars (Lepidoptera: Noctuidae) found on hairy fleabane plants (Conyza bonariensis) in Boa Vista do Incra and São Vicente do Sul

\begin{tabular}{|c|c|c|c|c|c|}
\hline Taxa & Total & Domin. $^{-1}$ & Abund. ${ }^{2 /}$ & Freq..$^{3 /}$ & Const. $^{4}$ \\
\hline Lepidoptera (Noctuidae) & \multicolumn{5}{|c|}{ Boa Vista do Incra } \\
\hline Anticarsia gemmatalis & 86 & $\mathrm{D}$ & va & $\mathrm{vf}$ & $\mathrm{Y}$ \\
\hline Spodoptera frugiperda & 63 & $\mathrm{D}$ & $\mathrm{c}$ & $f$ & $\mathrm{~W}$ \\
\hline Chrisodeixis includens & 47 & $\mathrm{D}$ & $\mathrm{c}$ & $\mathrm{f}$ & $\mathrm{W}$ \\
\hline Spodoptera eridania & 4 & ND & $\mathrm{d}$ & lf & $\mathrm{Z}$ \\
\hline Heliothis virescens & 3 & ND & $\mathrm{d}$ & lf & $\mathrm{Z}$ \\
\hline \multirow[t]{2}{*}{ Helicoverpa gelotopoeon } & 2 & ND & $\mathrm{d}$ & lf & $\mathrm{Z}$ \\
\hline & \multicolumn{5}{|c|}{ São Vicente do Sul } \\
\hline Anticarsia gemmatalis & 22 & $\mathrm{D}$ & $\mathrm{c}$ & $\mathrm{f}$ & $\mathrm{Y}$ \\
\hline Spodoptera frugiperda & 23 & $\mathrm{D}$ & $\mathrm{a}$ & vf & Y \\
\hline Chrisodeixis includens & 18 & $\mathrm{D}$ & $\mathrm{c}$ & $\mathrm{f}$ & $\mathrm{Z}$ \\
\hline Heliothis virescens & 5 & ND & $\mathrm{c}$ & $\mathrm{f}$ & $\mathrm{Z}$ \\
\hline Helicoverpa gelotopoeon & 1 & ND & $\mathrm{r}$ & lf & $\mathrm{Z}$ \\
\hline
\end{tabular}

1/ Dominance: ND (non-dominant); D (dominant); SD (super dominant); ${ }^{2} /$ Abundance: $\mathrm{r}$ (rare); d (dispersed); c (common); a (abundant); va (very abundant); sa (super abundant); $\underline{3} /$ Frequency: If (little frequent); f (frequent); vf (very frequent); sf (super frequent); ${ }^{4 /}$ Constancy: Z (accidental); Y (acessory); W (constant).

Chrysodeixis includens were dominant (D). The most common species in BVI was Anticarsia gemmatalis, with 86 individuals, followed by Spodoptera frugiperda, with 63 individuals, Chrysodeixis includens, with 47 individuals, Spodoptera eridania, with four individuals, Heliothis virescens, with three individuals and Helicoverpa gelotopoeon, with two individuals. S. frugiperda was the most common species in SVS, with 23 individuals, followed by $A$. gemmatalis, with 22 individuals, C. includens, with 18 individuals, $H$. virescens, with five individuals and $H$. gelotopoeon, with one individual. Previous studies on the spacetime distribution of soybean defoliating caterpillars found that where weed control was deficient, conditions became favorable for A. gemmatalis, C. includens and S. eridania (Stecca et al., 2011). A. gemmatalis was the most common species at both study sites and it was demonstrated that hairy fleabane was an important alternative host for this pest. This weed species was also an important alternative host for $S$. frugiperda, the main pest of corn, but it has been found to damage soybean leaves and pods over the last few years (Barros et al., 2010).

The population fluctuations of lepidoptera larvae in BVI and SVS (Figures 3 and 4, respectively) show that these species were present from the beginning of sampling in October (spring) until after the soybean harvest in June. The highest peaks occurred in January and March, when caterpillars normally occur in soybeans. Therefore, it can be seen that even when the crop is present as a food source, some larvae prefer hairy fleabane plants, demonstrating the role of this weed as an alternative host to lepidoptera larvae. In BVI, it was found that in the first

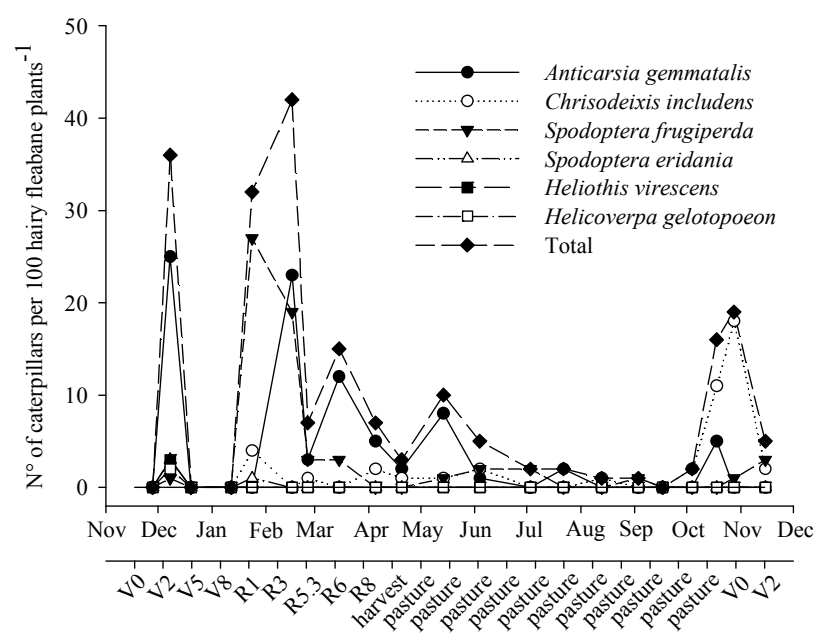

Figure 3 - Population fluctuations of Lepidoptera (Noctuidae) larvae associated with hairy fleabane plants (Conyza bonariensis) in Boa Vista do Incra, RS. 


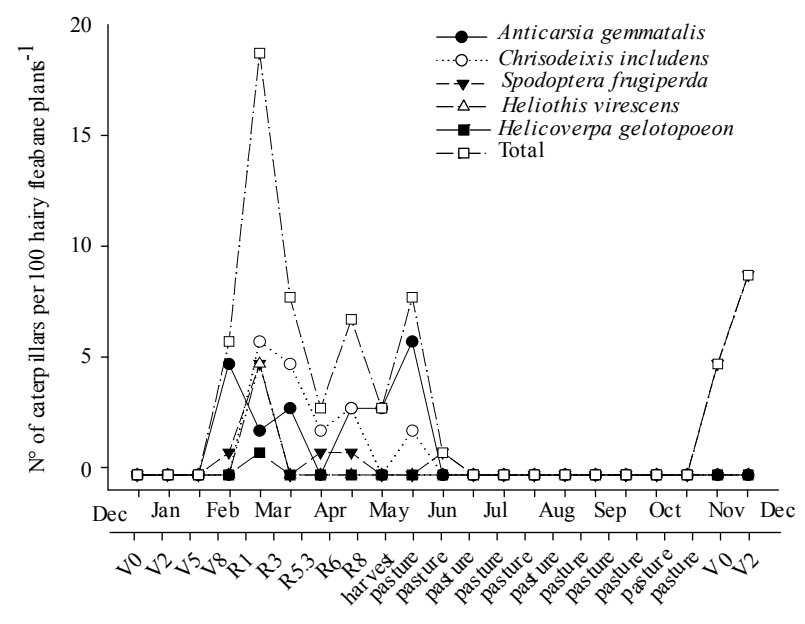

Figure 4 - Population fluctuations of Lepidoptera (Noctuidae) larvae associated with hairy fleabane plants (Conyza bonariensis) in São Vicente do Sul, RS.

samples, when soybean is at the beginning of development (V0-V2), there is a peak in the occurrence of $A$. gemmatalis on hairy fleabane plants. This shows the role of hairy fleabane as a shelter and food source for the first generations of caterpillars from the spring. In the same period, there were also individuals of other species of Lepidoptera, such as $S$. frugiperda and $H$. gelotopoeon.

At both study sites, after maturation of the soybeans in April, there was a new population peak of caterpillars on hairy fleabane, which may have been due the completion of a pest generation after soybean maturation and harvest. This fact indicates the caterpillars' mobility from soybean plants to hairy fleabane after crop senescence. A. gemmatalis has various generations per year in Brazil and part of the population survives on alternative host plants in the absence of soybeans (Panizzi et al., 2004). Between June and October, when there are no soybean crops and winter temperatures are low, practically no caterpillars were observed.

Therefore, hairy fleabane causes losses by competing for essential resources necessary for soybean growth and development and also acts as an alternative host to the main pest groups of the crop. This weed species is a host to soybean pentatomid stink bugs, especially Edessa meditabunda, Piezodorus guildinii and Euschistus heros, as well as lepidoptera larvae, mainly Anticarsia gemmatalis, Chrysodeixis includens and Spodoptera frugiperda. The population fluctuations of these species demonstrate that hairy fleabane is more important as an alternative host to caterpillars and stink bugs at the beginning of the summer crop, with production of the first generations of pests and also when soybean plants mature, serving as a food source so that the last generation can be completed before diapause. Therefore, weed control during the whole year is fundamental in order to eliminate alternative hosts for these pests.

\section{LITERATURE CITED}

Barros E.M. et al. Development of Spodoptera frugiperda on different hosts and damage to reproductive structures in cotton. Entomol Exp Appl. 2010;137:237-45.

Byerly K.F. et al. A comparison of sampling methods for some arthropod populations in cotton. Hilgardia. 1978;46:257-82.

Caballero-López B. et al. Weeds, aphids, and specialist parasitoids and predators beneût differently from organic and conventional cropping of winter cereals. J Pest Sci. 2012;85:81-8.

Christoffoleti P.J. et al. Glyphosate sustainability in South American cropping systems. Pest Manage Sci. 2008;64:422-7.

Corrêa-Ferreira B.S., Panizzi A.R. Percevejos da soja e seu manejo. Londrina: Embrapa Soja, 1999. 45p.

Corrêa-Ferreira B.S., Peres W.A.A. Comportamento da população dos percevejos-pragas e a fenologia da soja. In: Corrêa-Ferreira B.S., organizador. Soja orgânica: alternativas para o manejo dos insetos praga. Londrina: Embrapa Soja, 2003. p.27-32.

Dias A.C.R. et al. Competitiveness of alexandergrass or Bengal dayflower with soybean. Planta Daninha. 2010;28:515-22.

Foerster M.R. et al. How Trichogramma survives during soybean offseason in Southern Brazil and the implications for its success as a biocontrol agent. Biocontrol. 2015;60:1-11.

Greene G.L., Leppla N.C., Dickerson W.A. Velvetbean caterpillar: a rearing procedure and artificial medium. J Econ Entomol. 1976;69:487-8.

Hoffmann-Campo C.B., Corrêa-Ferreira B.S., Moscardi F. Soja; manejo integrado de insetos e outros artrópodes-praga. Brasília: Embrapa, 2012. 859p. 
Lamego FP., Vidal R.A. Resistência ao glyphosate em biótipos de Conyza bonariensis e Conyza canadensis no estado do Rio Grande do Sul, Brasil. Planta Daninha. 2008;26:467-71.

Lazaroto C.A. et al. Biologia e ecofisiologia de buva (Conyza bonariensis e Conyza canadensis). Ci Rural. 2008;38:85260 .

Moraes R.C.B., Haddad M.L. Software para análise faunística-ANAFAU. In: Resumos do Simpósio de Controle Biológico; 2003; Piracicaba. Piracicaba: Sociedade Entomológica do Brasil, 2003. p.195.

Moreira M.S. et al. Resistência de Conyza canadensis e Conyza bonariensis ao herbicida glyphosate. Planta Daninha. 2007;25:157-64.

Musolin D.L. Surviving winter: diapause syndrome in the southern green stink bug Nezara viridula in the laboratory, in the ûeld, and under climate change conditions. Physiol Entomol. 2012;37:309-22.

Norris R.F., Kogan M. Ecology interactions between weeds and arthropods. Ann Rev Entomol. 2005;50:479503.

Panizzi A.R. Ecologia nutricional de insetos sugadores de sementes. In: Panizzi A.R., Parra J.R.P., organizador. Ecologia nutricional de insetos e suas implicações no manejo de pragas. São Paulo: 1991. p.253-87.
Panizzi A.R. et al. Survivorship, larval development and pupal weight of Anticarsia gemmatalis (Hübner)

(Lepidoptera: Noctuidae) feeding on potential leguminous host plants. Neotr Entomol. 2004;33:563-7.

Panizzi A.R., Niva C.C. Overwintering strategy of the brown stink bug in northern Paraná. Pesq Agropec Bras. 1994;2:509-11.

Panizzi A.R., Vivan L.M. Seasonal abundance of the neotropical brown stink bug, Euschistus heros in overwintering sites and the breaking of dormancy. Entomol Exp Appl. 1997;82:213-7.

Stecca C.S. Distribuição espaço-temporal e flutuação populacional de lagartas desfolhadoras da soja [dissertação]. Santa Maria: Universidade Federal de Santa Maria, 2011.

Vargas L. et al. Buva (Conyza bonariensis) resistente ao glyphosate na região sul do Brasil. Planta Daninha. 2007;25:573-8.

Vila-Aiub M.M., Neve P., Powles S.B. Fitness costs associated with evolved herbicide resistance alleles in plants. New Phytol. 2009;184:751-67.

Young B.G. et al. Glyphosate translocation in common lambsquarters (Chenopodium album) and velvetleaf (Abutilon theophrasti) in response to ammonium sulfate. Weed Sci. 2003;5:151-6. 